Article

\title{
Enhancing Greenhouse Tomato-Crop Productivity by Using Brassica macrocarpa Guss. Leaves for Controlling Root-Knot Nematodes
}

\author{
Sergio Argento ${ }^{1}$, Maria Grazia Melilli ${ }^{1, *}$ and Ferdinando Branca ${ }^{2}$ (D) \\ 1 Institute for Agricultural and Forest Systems in the Mediterranean, National Council of Research Via \\ Empedocle n. 58, 95128 Catania, Italy; sergio.argento@cnr.it \\ 2 Department of Agricultural Sciences, Food and Environment-Di3A, University of Catania \\ Via Valdisavoia n. 5, 95123 Catania, Italy; fbranca@unict.it \\ * Correspondence: mariagrazia.melilli@cnr.it; Tel.: +39-095-6139916
}

Received: 10 October 2019; Accepted: 25 November 2019; Published: 29 November 2019

\begin{abstract}
Tomato crops are affected in Mediterranean cold-greenhouse agrosystems by soilborne diseases, such as root-knot nematodes (Meloidogyne spp.), which represent a serious problem leading to losses in production. Agroecological soil management based on biocontrol agents and natural compounds has had increased grower interest in order to reduce chemical residues in the produce and to adopt environmentally friendly farming methods. In this frame, we evaluate and validate soil biofumigation by the use of glucosinolate (GLS) compounds. Among them, sinigrin showed biocontrol activities against several pests and diseases via nematotoxic action. Among the Brassicaceae species rich in sinigrin, we chose Brassica macrocarpa Guss. (BM) because its leaves show $90 \%$ of all GLSs, and we could better estimate the action of this single GLS. Different dosages of BM leaf flour, containing 200 to 300, 350, 400, 450, and $650 \mu \mathrm{mol} \mathrm{m}{ }^{-2}$ of sinigrin, were inserted into soil already infected by Meloidogyne spp. for evaluating their effects on tomatoes grown in cold greenhouses in comparison to absolute control (CTRL) and to the chemical one, Vydate $5 \mathrm{G}^{\circledR}$ (CCTRL). The root disease index, caused by nematode attack, was the highest in CTRL, and a reduction of about 50\% was observed with the 300 to $650 \mu \mathrm{mol} \mathrm{m}^{-2}$ sinigrin dosage. The CCTRL showed twofold marketable yield increase, and a fourfold increase was found in $650 \mu \mathrm{mol} \mathrm{m}^{-2}$ of sinigrin dosage, in comparison to the CTRL. Biofumigant applications improved tomato plant growth and development, and fruit quality, significantly for dry matter and soluble sugars ( ${ }^{\circ}$ Brix). BM leaf flour inserted into the soil, at a dose of $300 \mu \mathrm{mol} \mathrm{m}{ }^{-2}$ of sinigrin, showed similar effects to the CCTRL on root disease index, root weight, and marketable yield. Data showed the nematotoxic effect of sinigrin for the biocontrol of Meloydogine spp. by the use of B. macrocarpa leaves, very rich in this GLS compound, which represents a new tool for agroecological soil management and for organic farming.
\end{abstract}

Keywords: biofumigation; Brassica macrocarpa; sinigrin; nematodes; sustainable agriculture

\section{Introduction}

The tomato (Solanum lycopersicum L.) is the most economically important vegetable crop in the world, and its cultivation covers about 5 million hectares, producing about 182 million tons. Italy is the main tomato producer in Europe with about $100,000 \mathrm{Ha}$, whereas economically important production is concentrated in cold-greenhouse agrosystems $(7229 \mathrm{Ha})$, of which about $50 \%$ production is concentered in Sicily $[1,2]$.

In cold-greenhouse agrosystems, nematodes cause serious phytosanitary problems, and losses in tomato production have been associated with pests and diseases, such as Meloidogyne spp. 
root-knot nematodes [3,4]. During the last few decades, several chemical pesticides have been utilized for controlling soilborne pests and diseases, increasing human and animal health risks as a consequence of their extreme toxicity as air, soil, and groundwater pollutants [5]. Moreover, restriction limits for conventional pesticide products with high environmental impact were outlined by Directive 2009/128/EC, strongly encouraging the use of natural products for plant management and protection in parallel with well-known agrotechniques for limiting soilborne diseases and increasing soil organic matter [6]. Alternative soil management with natural compounds or biocontrol agents for controlling pests and diseases in environmentally friendly farming systems, as well as in conventional ones, enables farmers to avoid and/or reduce the use of chemical pesticides [7]. Among several sustainable agro-echniques proposed for controlling soilborne-disease soil solarization, grafted plants and biofumigation seem interesting, but none could currently be a solution if not combined with different techniques [8]. Matthiessen and Kirkegaard [9] used the term 'biofumigation' to describe the process of growing, macerating, and incorporating Brassica species into the soil, leading to the release of isothiocyanate compounds (ITCs) through the hydrolysis of glucosinolate (GLS) compounds contained in plant tissue [10]. This could result in a suppressive effect on a range of soilborne pests and diseases without lingering on products [3]. GLSs are thioglucosidic secondary metabolites that are mainly present in the Brassicaceae and Capparidaceae families that, after hydrolysis by myrosinase, produce ITC derivatives with a chemical structure similar to soil fumigants with nematotoxic action [11]. The biofumigant effects of Brassicaceae biomass on Meloidogyne incognita [12,13], Meloidogyne chitwoodi [14,15], and Meloidogyne javanica [16], have been extensively reviewed [17,18]. In vitro studies showed interactions between pathogens and their sensitivity to different ITCs [19], and that they require different biofumigants for their effective control. Commonly used biofumigant compounds present in several Brassica species are represented by several GLSs that release different ITCs [20,21], of which the isothiocyanate allyl seems to be the most active against several pests and diseases [8]. Although some Brassicaceae species showed an articulated GLS profile, some of them presented prevalent GLS [22]. Within each Brassica species, different cultivars or plant organs may also contain different GLS amounts or profiles [23]. Brassica species, such as Brassica juncea, Raphanus sativus, and Eruca sativa, have already been investigated in previous studies, and they have been used as biocide plants for soilborne disease control $[15,24,25]$. Among Brassicaceae species, we have paid attention to Brassica macrocarpa (BM) because it has a high concentration of sinigrin in comparison to other species, with about $90 \%$ of its GLS profile represented by sinigrin [26]. It is an endemic wild Sicilian Brassica relative, present only in the islands of Favignana and Marettimo [27], where its populations are widespread. It has recently disappeared from Levanzo (Figure 1), and conservation and enhancement strategies have been activated $[27,28]$.

$\mathrm{BM}$ grows on rocky cleaves, and is endangered by human activity and animal grazing. All three islands of the Egadi archipelago have been monitored for collecting information about the sites and the structure of its populations, such as number of individuals, age, and amount of seeds produced per plant [27]. This perennial wild species has also been used in a breeding program with the aim of increasing aliphatic GLSs in broccoli breeding lines [29], especially glucoraphanin, to provide high amounts of the isothiocyanate sulforaphane, which is the most interesting ITC involved in cancer protection in mammals $[26,30,31]$. The present work aimed to evaluate the biofumigation effects of BM flour for soil biofumigation by increasing the dose of sinigrin inserted into the soil for controlling root-knot nematodes (Meloidogyne spp.) in tomato crops, in comparison to the absolute control (CTRL) and chemical control Vydate $5 \mathrm{G}^{\circledR}$ (CCTRL). 


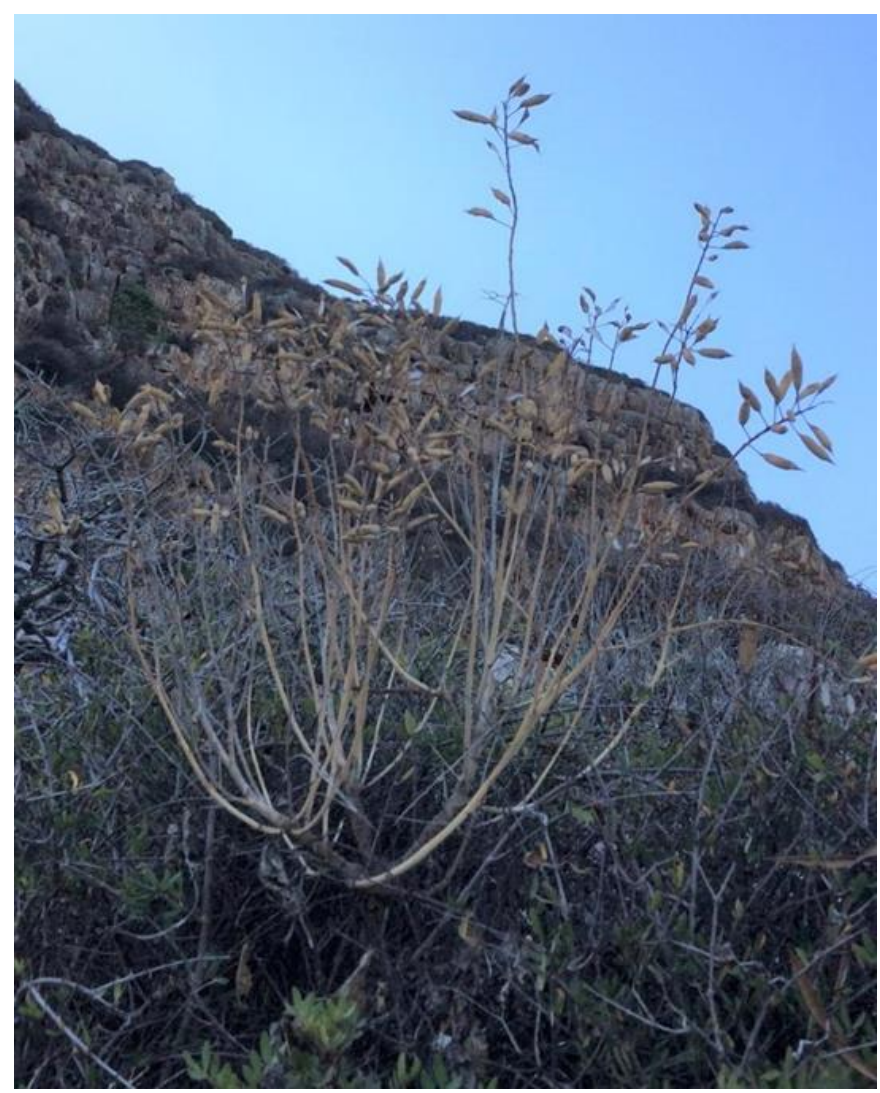

Figure 1. Wild Brassica macrocarpa Guss. in the island of Egadi.

\section{Materials and Methods}

\subsection{B. Macrocarpa Characterization and Production}

B. macrocarpa Guss. seed samples were provided by the Di3A (University of Catania, Italy) ex situ active Brassica collection (code accession UNICT 3253). Seeds were sown during the second week of August 2015 in alveolar trays utilizing a peat-based substrate, and placed in a cold greenhouse. The four-leaf-stage plants were transplanted after 60 days from sowing in a cold greenhouse at the experiment farm of Catania University, with a crop density of 2.5 plants $\mathrm{m}^{-2}$ (Figure 2). BM basal leaves were collected in February 2016, at the beginning of its reproductive phase, and in March 2016. All harvested leaves were immediately weighed and dried in a ventilated oven at $40 \pm 2{ }^{\circ} \mathrm{C}$ for about 2-3 days and milled to obtain its flour, fine enough for inserting into the soil. In order to determine sinigrin content, an aliquot of fresh leaves was immediately frozen in liquid nitrogen for GLS analysis.

At the end of April 2016, at the beginning of the seed-dispersal phase, we registered the main biomorphological descriptors (plant height, total number of leaves and ramifications, leaf form, and number of siliques per plant) and seed yield on $50 \mathrm{BM}$ plants. BM flour was divided into five samples for each agronomic replicate for qualitative-quantitative GLS determination by HPLC. 


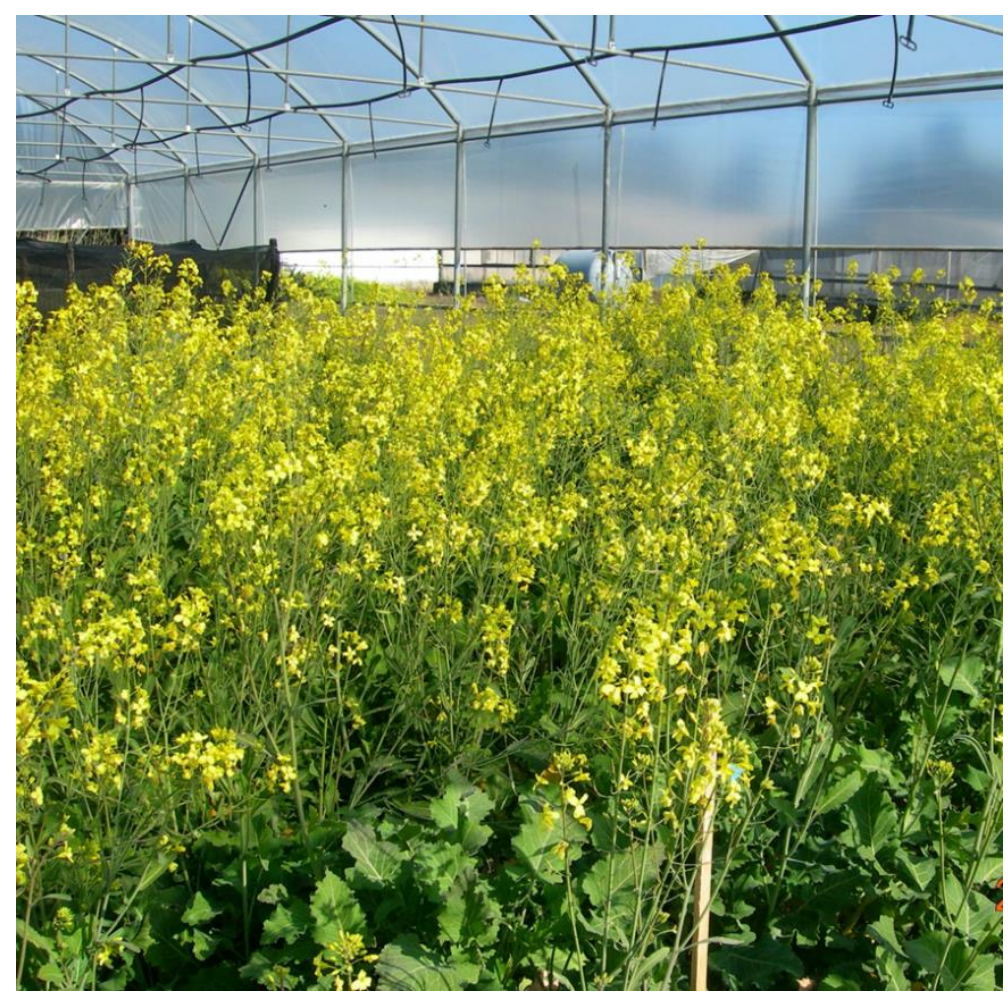

Figure 2. Brassica macrocarpa Guss. cropped in cold greenhouse for biofumigant production.

\subsection{Glucosinolate Quantitative Analysis}

The amount of sinigrin was determined in $\mu$ mol $\mathrm{g}^{-1 \text { d.w. }}$ on the basis of the EU official ISO 9167-1 method [32] with some modifications [33]. The GLS extraction protocol was carried out using 100 $\mathrm{mg}$ of the subsample. It was dissolved in $3 \mathrm{~mL} 70 \%$ ethanol at $70{ }^{\circ} \mathrm{C}$ for a few minutes in water-bath heating, vortexed, and subsequently centrifuged for $10 \mathrm{~min}$ at $4000 \mathrm{rpm}$. The supernatant was collected in $15 \mathrm{~mL}$ falcon tubes and stored; the pellet was subjected to another cycle in $70 \%$ ethanol in order to recover as many GLSs as possible. The obtained supernatants were collected and stored at -20 ${ }^{\circ} \mathrm{C}$. The extracted GLSs were then converted into desulfo-GLSs by using a microcolumn (BIORAD) as described below: adding $1 \mathrm{~mL}$ of resin DEAE e A-25 Sephadex (CAS Number 12609-80-2, Sigma Aldrich, MO, USA) previously conditioned at pH 5.6 in a $25 \mathrm{mM}$ acetate buffer into the column; the column was washed 3 times using $1 \mathrm{~mL} 25 \mathrm{mM}$ acetate buffer; $1 \mathrm{~mL}$ of the sample extract was slowly added in the buffer acetate, prepared, and then washed again; $100 \mu \mathrm{l}$ of a $0.5 \%$ solution of Helix pomatia sulfatase type H-1 (Sigma-Aldrich Chemie, Taufkirchen, Germany) was added, and the column was placed at $25 \pm 1{ }^{\circ} \mathrm{C}$ for $16 \mathrm{~h} ; 3 \mathrm{~mL}$ of deionized water was added in the column, and the eluent was finally collected from the column and stored at $-20^{\circ} \mathrm{C}$.

Afterwards, analysis was performed with a HPLC Agilent 1200 by Diode Array detector set at a wavelength of $229 \mathrm{~nm}$ [32], while the pump LS type was set to a flow rate of $1.0 \mathrm{~mL} \mathrm{~min}^{-1}$; the used column type was a $250 \times 4 \mathrm{~mm}$ Lichrospher conditioned at $30^{\circ} \mathrm{C}$.

\subsection{Tomato Experiment Field}

The experiment trial was carried out at Scoglitti (8 m a.s.l., latitude: $36^{\circ} 53^{\prime} 0^{\prime \prime} \mathrm{N}$, longitude: $14^{\circ} 25^{\prime} 0^{\prime \prime}$ E) on the southern coast of Sicily (Scoglitti, Italy), at the largest concentration of greenhouses in Italy devoted to tomato production. The trial was conducted in a representative farm, in a cold greenhouse characterized by a concrete and wood structure covered with polyethylene film. This type of soil, and the tomato monoculture growing system usually adopted, favors the diffusion of nematode attacks in cold greenhouses in Sicily during the spring and summer seasons. The soil was represented by a 
medium loamy sand type consisting of $13.5 \%$ clay, $20.8 \%$ silt, and $65.7 \%$ sand, with $1.6 \%$ of organic matter and $\mathrm{pH} 6.2\left(\mathrm{CaCl}_{2}\right)$.

\subsection{Sinigrin Effect for Controlling Root Knot Nematodes (Meloidogyne spp.)}

The effectiveness of BM flour, and then of sinigrin, was tested for controlling root-knot nematodes (Meloidogyne spp.) in a tomato greenhouse by using the cultivar 'Ikram $\mathrm{F}_{1}$ ' (Syngenta) susceptible to them but resistant to Fol: 0-1 (Fusarium oxysporum f.sp. Lycopersici race 0,1), to ToMV: 0-2 (Tomato Mosaic Virus strain 0-2), to Va: 0 (Verticillium albo-atrum race 1), and to Vd: 0 (Verticillium dahliae race 1). The experiment field was established by adopting a completely randomized block experiment design with four replicates. The experiment factor was represented by the sinigrin dose inserted by the BM flour, previously titrated, ranging from 0 (CTRL) to 200, 300, 350, 400, 450, and $650 \mu \mathrm{mol}$ $\mathrm{g}^{-1}$ d.w. $\mathrm{m}^{-2}$ of sinigrin. CCTRL was represented by the Vydate $5 \mathrm{G}^{\circledR}$ (Dupont) fumigant based on Oxamyl 5\%, utilized at the dose suggested by the company. Ten days before transplanting and at the end of the growing cycle, soil samples were collected for estimating the root disease index for nematodes in the laboratory according to Cobb's decanting and sieving method [34]. In particular, before transplanting, we fractioned the greenhouse area in 24 sections from which we collected soil samples in a zig-zag pattern as a soil probe until $20 \mathrm{~cm}$ deep. Samples were kept in a cool bag until their delivery to the laboratory. At the end of the growing cycle, three soil samples were analyzed for each thesis, corresponding to the studied sinigrin doses.

After that, we inserted BM flour into the first $10 \mathrm{~cm}$ of soil at the above doses, whereas we inserted nothing for the CTRL, and the recommended dose of Vydate $5 \mathrm{G}^{\circledR}\left(6.5 \mathrm{~g} \mathrm{~m}^{-2}\right)$ for the CCTRL. The tomato seedlings were transplanted after 10 days along single rows, adopting a crop density of 3.3 plant $\mathrm{m}^{-2}$; each replicant was represented by 15 plants. The plot size was $4.5 \mathrm{~m}^{2}$. Thirty days from transplanting, all previously used sinigrin doses were utilized again, burying them about $10 \mathrm{~cm}$ deep into the soil in parallel grooves to the rows near the root system. The plants were grown with a single stem, removing secondary shoots, and pruning it above the fifth cluster. The plants were drip-irrigated with an ordinary schedule. A microflow drip-irrigation method was used with dripping wings and distributors giving $2 \mathrm{~L} \mathrm{~h}^{-1}$, spaced $20 \mathrm{~cm}$ along the row. The nutritional requirements were satisfied by a fertigation system coupled with an electronic timer, scheduled on the basis of evapotranspiration values by Penmam-Monteith [35]. The ratio of $\mathrm{N}: \mathrm{P}_{2} \mathrm{O}_{5}: \mathrm{K}_{2} \mathrm{O}$ was 1: $0.4: 1.8$ as a whole.

In addition to the ordinary managements for tomato crop (tutoring, suckering, etc.), the root systems and canopy were also monitored in order to observe any signals of attacks attributed to root-knot nematodes.

\subsection{Root Nematode Infestation and Fruit Yield and Quality}

At the end of the growing cycle, 140 days after transplanting, the fresh weight of the root system was recorded for all plants grown in the cold greenhouse. The efficacy of sinigrin treatments was determined by calculating the Disease Index (DI) on the root systems in relation to nematode infection. Referring to nematode attack, the root system was inspected for galls according to a rating scale of $0-5$, taking into account gall size and the attacked surface of roots [36].

The DI was calculated as the weighted average of root infestation, rated according to a $0-5$ scale: $0=$ no galls - healthy plant; $1=1-5$ galls - very slight damage; $2=6-20$ galls - moderate damage; $3=$ more than 20 galls - medium damage; $4=$ root system reduced and root physiology altered by some large galls; $5=$ root system completely destroyed $[4,36]$.

The number and weight of the fruits were recorded for each cluster of 10 plants for each plot; the marketable fruits of the harvested ones were detected.

The fruits of the fourth cluster were analyzed for quality parameters: single fresh fruit weight

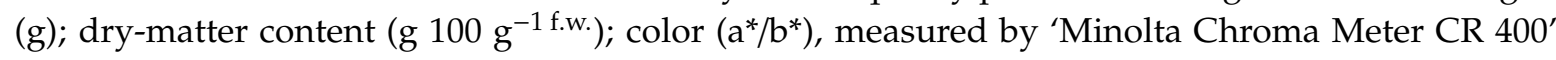
(Minolta Camera Co. LTD, Osaka, Japan); $\mathrm{a}^{*}$ and $\mathrm{b}^{*}$ are the Commission International d'Eclairage (CIE) chromatic coordinates that indicate, respectively, the red-green and yellow-blue components. On the 
homogenized pulp, soluble solids (SS, ${ }^{\circ}$ Brix), measured with a digital refractometer (DBR95, Geass, Torino, Italy) and $\mathrm{pH}$ were read with a glass electrode $\mathrm{pH}$ meter.

\subsection{Statistical Analysis}

Data were analyzed to Barlett's test for variance homogeneity, and then analysis of variance. Means were statistically separated on the basis of Duncan's test when the F test of analysis of variance for treatment was significant at least at the 0.05 probability level. Significance was accepted at the $p<0.05$ level. Principal component analysis was performed on the raw data without any prior scaling in order to avoid the generation of a singular correlation matrix, and the highest correlating variables (Pearson's $R>0.95$ ) were removed from the model [37].

\section{Results}

\subsection{B. Macrocarpa Characterization and Production}

BM reached the reproductive phase after 120 days from transplanting. The main morphological and chemical plant descriptors registered after 180 days from transplanting are presented in Table 1, showing a very vigorous plant in comparison with wild ones, which are smaller in natural environmental conditions [38]. The plant after 6 months from transplanting was about $53 \mathrm{~cm}$ high, with about 5 secondary branches and about 50 leaves, producing about $11.0 \mathrm{~g}$ of seeds and a leaf yield of $473 \mathrm{~g}$ (Table 1). The BM leaves collected at 120 (February 2016) and 150 days (March 2016) after transplanting provided a total yield of $1183 \mathrm{~g} \mathrm{~m}^{-2}$ fresh leaves, with a dry matter content of 13.4

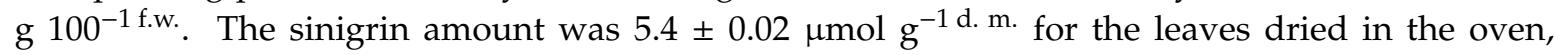
and $5.9 \pm 0.02 \mu \mathrm{mol} \mathrm{g}{ }^{-1} \mathrm{~d} . \mathrm{m}$. for the freeze-dried leaves. To incorporate the BM flour into the soil to obtain the different dosages, we took into account the sinigrin concentration of the leaves dried in the oven, which represents a faster and easier biofumigation method to transfer to farmers for their own production of biofumigants.

Table 1. Biomorphological characterization of Brassica macrocarpa Guss. after 180 days of growth $(n=50$ plants).

\begin{tabular}{|c|c|c|}
\hline & & IBPGR and UPOCV Descriptors [27] \\
\hline Plant height $(\mathrm{cm})$ & $53.4 \pm 7.6$ & 65.3 \\
\hline Number of secondary branches (plant ${ }^{-1}$ ) & $5.2 \pm 2.0$ & 7.0 \\
\hline Number of leaves (plant ${ }^{-1}$ ) & $49.6 \pm 3.1$ & 50.6 \\
\hline Leaf-blade width (cm) & $11.3 \pm 0.9$ & 5.7 \\
\hline Leaf-blade length $(\mathrm{cm})$ & $30.0 \pm 4.6$ & 26.3 \\
\hline Petiole length (cm) & $13.6 \pm 2.7$ & 24.4 \\
\hline Number of siliques (plant ${ }^{-1}$ ) & $50.0 \pm 7.0$ & \\
\hline Number of seeds (silique ${ }^{-1}$ ) & $10.0 \pm 1.4$ & \\
\hline Seed yield $\left(\mathrm{g}_{\text {plant }}{ }^{-1}\right)$ & $11.0 \pm 1.5$ & \\
\hline Fresh-leaf yield (g plant ${ }^{-1}$ ) & $473 \pm 35$ & \\
\hline Dry-matter content (g $100^{-1}$ f.w.) & $13.4 \pm 0.6$ & \\
\hline Dry-leaf sinigrin content ( $\left.\mu \mathrm{mol} \mathrm{g}^{-1} \mathrm{~d} . \mathrm{m}.\right)$ & $5.4 \pm 0.05$ & \\
\hline Fresh-leaf sinigrin content $\left(\mu \mathrm{mol} \mathrm{g}^{-1 \text { f.w. }}\right)$ & $5.9 \pm 0.06$ & \\
\hline
\end{tabular}

\subsection{Root Nematodes Infestation and Fruit Yield and Quality}

The larvae number of second age of Meloidogyne spp., expressed per $100 \mathrm{~cm}^{3}$ of soil, was $1416 \pm 50.2$ in the soil samples collected before transplanting (T0), whereas at the end of the growing cycle (T1), it was about $1250 \pm 35.4$ for CTRL and $385 \pm 15.2$ for CCTRL. The sinigrin dose of $300 \mu \mathrm{mol} \mathrm{g}{ }^{-1}$ d.w. showed the same number of larvae registered for CCTRL and the highest recorded dose of $650 \mu \mathrm{mol} \mathrm{g}{ }^{-1}$ d.w. was about $100 \pm 3.5$, i.e., twelve times less than for the CTRL, and about four times for CCTRL (Table 2). 
Table 2. Number of larvae of second age of Meloidogyne spp. (n. per $100 \mathrm{~cm}^{3}$ ) at beginning (T0) and end of productive cycle (T1).

\begin{tabular}{ccc}
\hline \multirow{2}{*}{ Sinigrin Dosage } & \multicolumn{2}{c}{ Larvae of Second Age } \\
\cline { 2 - 3 } & T0 & T1 \\
\hline CTRL & $1416 \pm 50.2$ & $1250 \pm 35.4^{\mathrm{a}}$ \\
CCTRL & & $385 \pm 15.2^{\mathrm{b}}$ \\
200 & $1100 \pm 28.0^{\mathrm{a}}$ \\
300 & $400 \pm 11.3^{\mathrm{b}}$ \\
350 & $370 \pm 7.8^{\mathrm{b}}$ \\
400 & $270 \pm 3.8^{\mathrm{c}}$ \\
450 & $180 \pm 3.1^{\mathrm{d}}$ \\
650 & $100 \pm 3.5^{\mathrm{e}}$ \\
Mean & $507 \pm 14.2^{2}$ \\
LSD $(p<0.05)$ & $14.5^{* * *}$ \\
$p$ & & $* 0.05)$ \\
\hline
\end{tabular}

Values followed by different letters within each column were significantly different $(p<0.05)$ by Duncan's multiple range test $(n=4)$. ${ }^{* * *}$ Significant at $p=0.001$ probability level.

The DI on the root surfaces, due to nematode disease, showed the highest values for CTRL; using BM flour rich in sinigrin led to attack reduction (Figure 1). The highest DI value of about 3.6 was observed for CTRL, which was reduced by about $50 \%$ for CCTRL. For all the used sinigrin doses, DI values were lower than those for CTRL (Figure 1). The DI was inversely correlated with root weight (Figure 1). In fact, the lowest DI determined the highest value of root weight, which was 64.4, 75.7, and $102.3 \mathrm{~g} \mathrm{plant}^{-1}$ for CTRL, CCTRL, and the highest tested dose of sinigrin, respectively (Figure 3; Figure 4). Even if the root system was significantly affected by sinigrin dosages, the registered values for biometric root parameters (number of clusters per plant and stem diameter) 60 days after transplanting to evaluate the effect of sinigrin on plant growth rate during the tomato growing cycle did not show any statistical differences in comparison to the CTRL. In particular, the number of clusters per plant was $4.6 \pm 0.3$, and stem diameter of $13.7 \pm 0.1 \mathrm{~mm}$ on the mean of all treatments (Table 3).

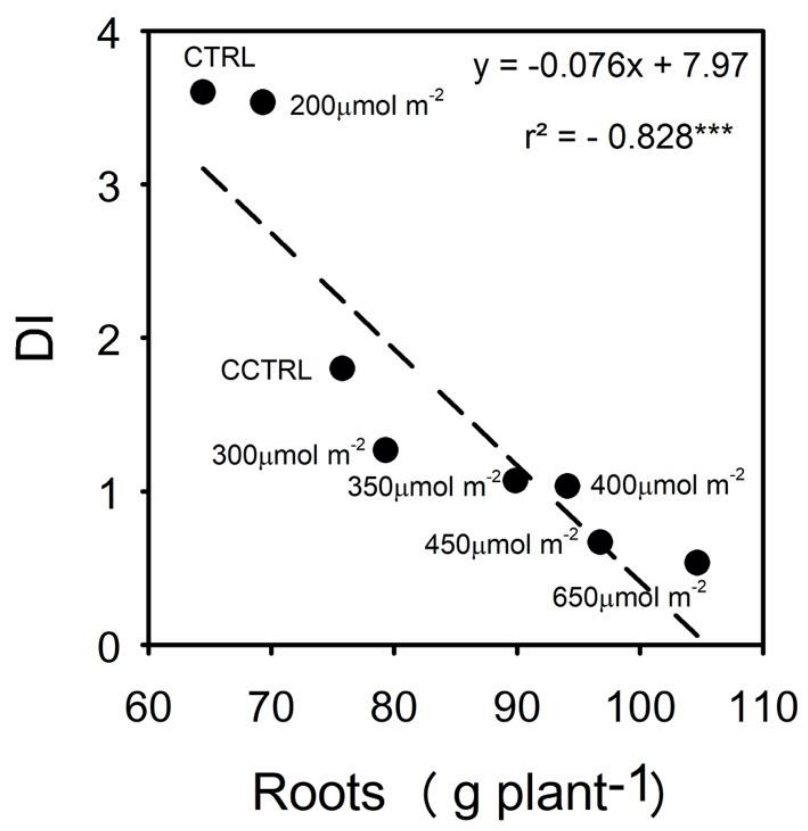

Figure 3. Correlation between root biomass production $\left(\mathrm{g} \mathrm{plant}^{-1}\right)$ and nematode Disease Index (DI). 


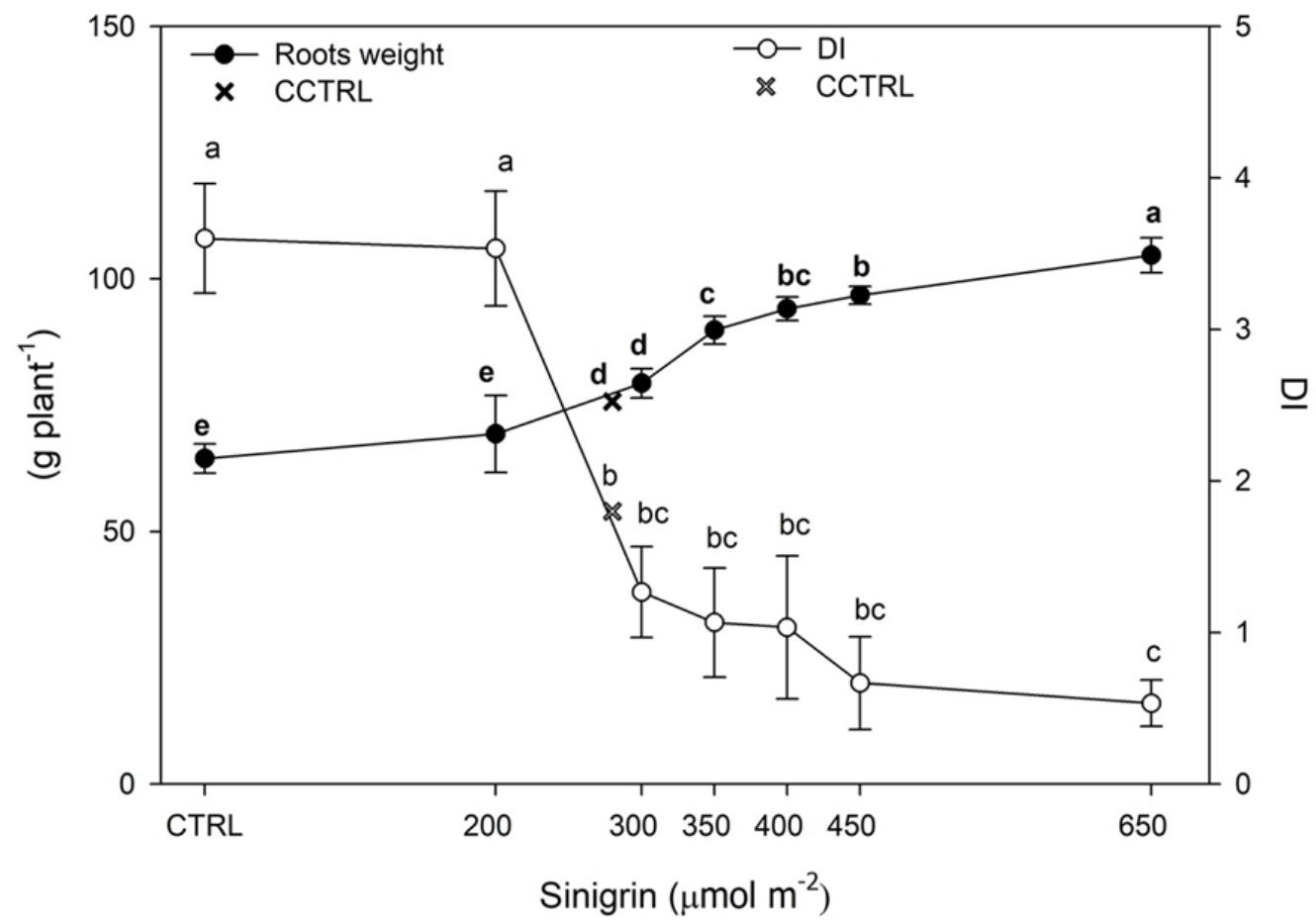

Figure 4. Recorded root weight $\left(\mathrm{g}_{\text {plant }}{ }^{-1}\right.$ ) and DI in relation to different sinigrin dosages. Different letters indicate statistical differences at $p<0.05$.

Table 3. Number of fruits and clusters per plant (n.), fruit weight (g), and tomato fruit quality parameters in relation to sinigrin doses at productive-cycle end.

\begin{tabular}{|c|c|c|c|c|c|c|c|c|}
\hline \multirow{2}{*}{$\begin{array}{c}\text { Sinigrin } \\
\text { Dosage }\end{array}$} & \multirow{2}{*}{$\begin{array}{c}\text { Fruits } \\
\text { (n) }\end{array}$} & \multirow{2}{*}{$\begin{array}{c}\text { Clusters } \S \\
\text { (n) }\end{array}$} & \multirow{2}{*}{$\begin{array}{c}\begin{array}{c}\text { Fruit } \\
\text { Weight }\end{array} \\
(\mathrm{g})\end{array}$} & \multicolumn{2}{|c|}{$\begin{array}{c}\text { Chromatic } \\
\text { Parameters (CIE) }\end{array}$} & \multirow{2}{*}{$\begin{array}{c}\text { Soluble } \\
\text { Sugars }\end{array}$} & \multirow{2}{*}{$\begin{array}{c}\text { Dry Matter } \\
\%\end{array}$} & \multirow[t]{2}{*}{$\mathrm{pH}$} \\
\hline & & & & $(\mathrm{L})$ * & $a / b$ & & & \\
\hline CCTRL & $26.2 \pm 0.2^{d}$ & $4.5 \pm 0.1^{\mathrm{a}}$ & $67.8 \pm 2.3^{a, b}$ & $39.9 \pm 1.7^{\mathrm{a}}$ & $1.90 \pm 0.18^{a}$ & $6.8 \pm 0.1^{b}$ & $7.7 \pm 0.3^{c}$ & $6.4 \pm 0.3^{a}$ \\
\hline 200 & $15.3 \pm 1.2 \mathrm{e}$ & $4.6 \pm 0.2^{\mathrm{a}}$ & $63.7 \pm 1.9^{b, c}$ & $36.9 \pm 1.9^{a}$ & $1.50 \pm 0.20^{a}$ & $7.3 \pm 0.1^{\mathrm{a}, \mathrm{b}}$ & $8.2 \pm 0.3^{a, b, c}$ & $5.7 \pm 0.5^{\mathrm{a}}$ \\
\hline 300 & $30.2 \pm 0.3^{c, d}$ & $4.5 \pm 0.3^{a}$ & $74.3 \pm 2.6^{a}$ & $40.6 \pm 3.2^{a}$ & $1.58 \pm 0.21^{\mathrm{a}}$ & $7.3 \pm 0.5^{a, b}$ & $8.3 \pm 0.4^{a, b, c}$ & $6.5 \pm 0.4^{\mathrm{a}}$ \\
\hline 450 & $44.1 \pm 1.7^{\mathrm{b}}$ & $4.6 \pm 0.2^{\mathrm{a}}$ & $70.1 \pm 4.9^{a, b}$ & $39.4 \pm 4.2^{\mathrm{a}}$ & $1.75 \pm 0.32^{a}$ & $7.3 \pm 0.2^{a, b}$ & $8.3 \pm 0.2^{a, b, c}$ & $6.1 \pm 0.2^{\mathrm{a}}$ \\
\hline 650 & $54.3 \pm 1.0^{\mathrm{a}}$ & $4.6 \pm 0.1^{\mathrm{a}}$ & $66.0 \pm 3.6^{b, c}$ & $39.0 \pm 2.9^{\mathrm{a}}$ & $1.72 \pm 0.34^{\mathrm{a}}$ & $7.5 \pm 0.4^{\mathrm{a}}$ & $8.8 \pm 0.5^{\mathrm{a}}$ & $6.3 \pm 0.3^{a}$ \\
\hline Mean & 32.8 & 4.6 & 66.0 & 38.9 & 1.65 & 7.29 & 8.29 & 6.19 \\
\hline $\operatorname{LSD}(p<0.05)$ & 6.96 & 0.43 & 6.78 & 5.27 & 0.45 & 0.58 & 0.80 & 0.96 \\
\hline$p$ & $* * *$ & ns & $* *$ & ns & ns & $*$ & * & ns \\
\hline
\end{tabular}

Values followed by different letters within each column were significantly different $(p<0.05)$ by Duncan's multiple range test $(n=5) ; \S 60$ days after transplanting; $\left({ }^{* * *}\right)\left({ }^{* *}\right)\left({ }^{*}\right)$ Significant at $p=0.001 ; 0.01$ and 0.05 probability level, respectively; $\mathrm{ns}=$ not significant.

The marketable fruit yield ranged between 890 and $3580 \mathrm{~g} \mathrm{plant}^{-1}$ for CTRL and CCTRL, respectively (Figure 5). Treatment at $300 \mu \mathrm{mol} \mathrm{m}{ }^{-2}$ of sinigrin increased marketable fruit yield in comparison to CCTRL (Figure 5). The high correlation index $\left(r^{2}=0.898^{* * *}\right)$ indicates the highest dose of sinigrin leading to fourfold yields compared to the CTRL. The lowest dose of sinigrin had the same results for CTRL. The effect of sinigrin dose began to be visible starting from $300 \mu \mathrm{mol} \mathrm{m}^{-2}$, and it was stable until $450 \mu \mathrm{mol} \mathrm{m}^{-2}$. The marketable-yield increase was more positively correlated with the number of fruits per plant produced than fruit weight, probably due to the biofumigated healthy root system of the plant that improved the fruit setting (Table 3). Concerning to the number of fruits per plant, which were on average 32.8, value ranged from 13.9 for CTRL to over 50 for the dose of sinigrin of $650 \mu \mathrm{mol} \mathrm{m}{ }^{-2}$. Fruit weight varied from $59.1 \pm 2.8 \mathrm{~g}$ to $74.3 \pm 2.6 \mathrm{~g}$ for the 350 and the $300 \mu \mathrm{mol} \mathrm{m}^{-2}$

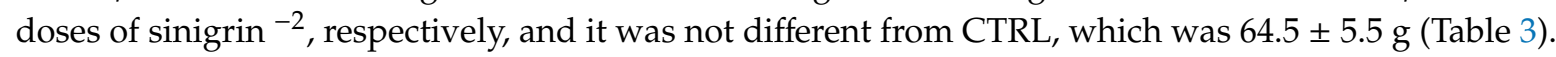




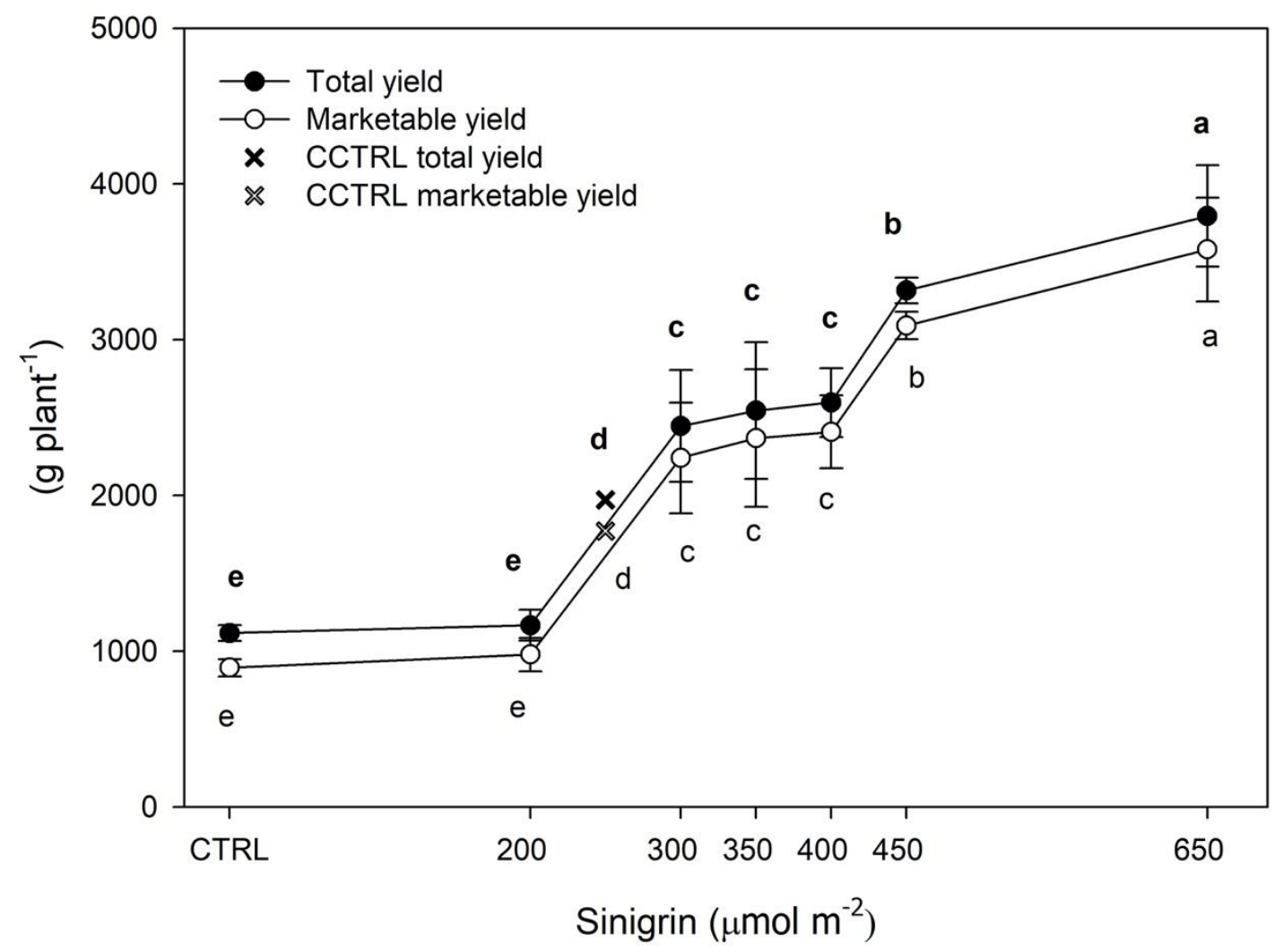

Figure 5. Total and marketable yields of tomato crop $\left(\mathrm{g} \mathrm{plant}^{-1}\right)$ in relation to different sinigrin dosages. Different letters indicate statistical differences at $p<0.05$.

\subsection{Fruit-Quality Parameters}

The effect of treatments on fruit quality is reported in Table 2. Color parameter $\mathrm{L}^{*}$ and $\mathrm{a}^{*} / \mathrm{b}^{*}$ ratio were not affected by sinigrin, with mean values of 38.9 and 1.65 , respectively. The biofumigant treatments affected fruit quality in terms of dry matter (DM), which positively influenced the soluble sugar content ( ${ }^{\circ}$ Brix). The dry matter was $8.3 \mathrm{~g} 100 \mathrm{~g}^{-1 \text { f.w. }}$ on the mean of all treatments, while we

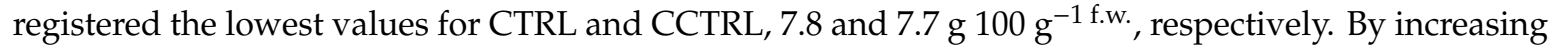
the sinigrin dose, fruit DM increased by about $1 \%$, reaching the value of $8.8 \mathrm{~g} 100 \mathrm{~g}^{-1 \text { f.w. }}$. The soluble sugar value ranged from $6.8 \pm 0.1$ to $7.5 \pm 0.4^{\circ}$ Brix, with an average value of $7.29 \pm 0.28^{\circ}$ Brix (Table 3).

\section{Discussion}

Brassica macrocarpa leaves showed a good amount of sinigrin, suggesting that this species, among other Brassicacea species with nematotoxic activity, could be utilized as biofumigant for environmentally friendly farming systems. Inserting different amounts of dried leaves and obviously different doses of sinigrin into the spoil affected DI, root weight, marketable yield, and fruit quality in greenhouse tomato production. The sinigrin dose of $300 \mu \mathrm{mol} \mathrm{m}^{-2}$ showed similar values for roots weight $\left(\mathrm{g}\right.$ plant ${ }^{-1}$ ) and DI as those ascertained for CCTRL, reducing DI and increasing root weight for the $650 \mu \mathrm{mol} \mathrm{m}{ }^{-2}$ sinigrin dose.

The marketable fruit yield was correlated with the fourfold DI yield for the highest utilized dose of sinigrin. Several authors have studied the effects of Brassicaceae spp. for its possible use as biofumigant [15,39-41], but no data are available related to the amount of sinigrin inserted into the soil by green manure or by seed-oil meal, and to the related effects on tomato-fruit quality of the most important crop grown in greenhouses in Italy.

Nematode attacks in greenhouses are a real threat for farmers in Italy, especially in the southern coastal area of Sicily, where 70\% of Italian tomato production is concentered. Several authors evaluated 
the effective nematocidal control of biofumigants on crops grown in pots $[21,25,42,43]$. In order to provide a useful applicative tool for farmers, we focused mainly on marketable fruit yield and tomato health in relation to the sinigrin dose inserted into the soil. Previous studies showed a biotoxic effect of sinigrin applied at transplanting or after one week on tomato growth, so we chose to use this biofumigant two weeks before transplanting. However, the adopted protocol for monitoring the number of larvae in each treatment was not so useful considering nematode motility in relation to soil temperature, water availability, and other variables. In any case, the effect of sinigrin was clear at the end of the growing cycle (end of July), as the number of larvae of second age of Meloidogyne spp. per $100 \mathrm{~cm}^{3}$ into the soil was significantly reduced at the highest utilized dose (lower than 100 larvae using $650 \mu \mathrm{mol} \mathrm{m}^{-2}$ ). Our results are in line with Avato et al. [17], who reported that GLS use as biofumigants in potatoes, tomatoes, and grapevines can be an effective tool for the sustainable management of phytoparasitic nematodes. Soil biofumigation with fresh or dry brassicaceous biomasses can be particularly useful in both organic and conventional agrosystems, but it is strictly related to GLS amount and profile. The same results were obtained by [24], using B. juncea granulated seed meal for controlling Melolontha spp. Grub mortality was significantly dependent on applied GLS concentration with the granulate. In tomato plants, defatted seed meal from B. carinata showed good results in terms of efficiency in controlling Meloidogyne incognita and agricultural environmental impact. Therefore, GLS application should also be considered as a potential alternative tool for controlling nematodes as it could improve soil biodiversity, offering a potential alternative to chemical fumigants [6]. The percentage of reduction of $M$. javanica larvae into the soil amended with mustard enhanced the quality of tomato fruits, such as total sugars, total amino acids, and total phenols [16]. Daneel et al. [42] tested two CVs of different species of Brassicaceae (Eruca sativa, Brassica juncea, and Raphanus sativus) as biofumigants against $M$. incognita and $M$. javanica in tomato and potato crops. The authors found that none of the Brassicaceae biofumigants used for potato crop significantly reduced the population levels of M. incognita, whereas some effects were ascertained for tomato crops in relation to used CVs. Our results agree with the positive effect of Brassicacea species used as biofumigants even if there are no indications for the amount and the profile of the GLSs of the used plant materials. Brassicaceae species are also incorporated as cover crop, but the obtained results could be related to the increase of beneficial nematode assemblages in soils treated with it. It is important to keep in mind that a significant proportion of plant GLSs can persist unhydrolyzed in the soil for several days after Brassicaceae biomass incorporation into the soil. Non-ITC liberating GLSs (predominately indolyl GLSs) from rape (Brassica napus) and Ethiopian mustard (Brassica juncea) were found at lower concentrations than ITC-liberating GLSs, but tended to persist longer in the soil [22]. This means that the time used for the natural decomposition process and the chemical transformation to reactive nematicidal molecules acts as a controlled release translated to a longer residual nematicidal activity under field conditions. Moreover, the risk of development of nematode resistance is relatively very low since the raw material used for soil amendment is a complex cluster of chemically different nematocidal components [8].

\section{Conclusions}

The use of Brassica macrocarpa as a biofumigant against nematodes produced a significant stimulant effect on the roots of tomato plants, which was reflected on tomato fruit yield and its qualitative characteristics. Different authors studied Brassica spp. for its potential use as a biofumigant but no data are available for B. macrocarpa use with regard to the amount and profile of GLSs incorporated into the soil, and very few reports are related to analysis of fruit-quality characteristics in relation to used biofumigant biomasses.

Our activities indicate the high potential of B. macrocarpa for the development of new nematocidal fumigant formulations, sustainable for the environment and human health. In addition, our results suggest that the biocidal activity largely depends on GLS profile and inserted dose into the soil, and show the effects of their use on root weight and nematode disease index. The highest tomato marketable yield and fruit quality were obtained at the highest sinigrin dose we utilized $\left(650 \mu \mathrm{mol} \mathrm{m}{ }^{-2}\right)$. 
Incorporating the dry-leaf flour of B. macrocarpa into the soil before the establishment of the susceptible nematode crop is an effective and easy practice to control this pest, which could easily be transferred to farmers for dissemination.

Author Contributions: Data curation, S.A. and M.G.M.; Investigation, S.A.; Methodology, F.B.; Supervision, F.B.; Writing - original draft, M.G.M. All authors discussed the results and contributed to the final manuscript.

Funding: This research was partially supported by the project BRESOV (Breeding for Resilient, Efficient and Sustainable Organic Vegetable production) funded by EU H2020 Programme SFS-07-2017 Contract number 774244. BRESOV allowed us to complete the work with plant material under study also in the project, such as Brassica macrocarpa Guss.

Conflicts of Interest: No potential conflict of interest was reported by the authors.

\section{References}

1. Faostat. Available online: http://www.fao.org/faostat/en/\#home (accessed on 9 October 2019).

2. ISTAT. Available online: https://www.istat.it/ (accessed on 9 October 2019).

3. Collange, B.; Navarrete, M.; Peyre, G.; Mateille, T.; Tchamitchian, M. Root-knot nematode (Meloidogyne) management in vegetable crop production: The challenge of an agronomic system analysis. Crop Prot. 2011, 30, 1251-1262. [CrossRef]

4. Argento, S.; Raccuia, S.A.; Melilli, M.G.; Toscano, V.; Branca, F. Brassicas and their glucosinolate content for the biological control of root-knot nematodes in protected cultivation. Acta Hortic. 2013, 1005, 539-544. [CrossRef]

5. Onkendi, E.M.; Kariuki, G.M.; Marais, M.; Moleleki, L.N. The threat of root-knot nematodes (Meloidogyne spp.) in Africa: A review. Plant Pathol. 2014, 63, 727-737. [CrossRef]

6. Mocali, S.; Landi, S.; Curto, G.; Dallavalle, E.; Infantino, A.; Colzi, C.; d'Errico, G.; Roversi, P.F.; D'Avino, L.; Lazzeri, L. Resilience of soil microbial and nematode communities after biofumigant treatment with defatted seed meals. Ind. Crops Prod. 2015, 75, 79-90. [CrossRef]

7. Zhou, L.; Yuen, G.; Wang, Y.; Wei, L.; Ji, G. Evaluation of bacterial biological control agents for control of root-knot nematode disease on tomato. Crop Prot. 2016, 84, 8-13. [CrossRef]

8. Ntalli, N.; Caboni, P. A review of isothiocyanates biofumigation activity on plant parasitic nematodes. Phytochem. Rev. 2017, 16, 827-834. [CrossRef]

9. Matthiessen, J.; Kirkegaard, J. Biofumigation and enhanced biodegradation: Opportunity and challenge in soilborne pest and disease management. CRC Crit. Rev. Plant Sci. 2006, 25, 235-265. [CrossRef]

10. Villalta, O.; Wite, D.; Riches, D.A.; Guiano, J.; Chandolu, V.; Scoble, C.; Donald, C.; Porter, I.J.; Mattner, S.W. The Concentration of 2-Propenyl Glucosinolate in Biofumigant Crops Influences Their Anti-Fungal Activity (In-Vitro) against Soil-Borne Pathogens. J. Agric. Chem. Environ. 2016, 5, 38-45. [CrossRef]

11. D'Addabbo, T.; Laquale, S.; Lovelli, S.; Candido, V.; Avato, P. Biocide plants as a sustainable tool for the control of pests and pathogens in vegetable cropping systems. Ital. J. Agron. 2014, 9, 137-145. [CrossRef]

12. Lazzeri, L.; Leoni, O.; Manici, L.M. Biocidal plant dried pellets for biofumigation. Ind. Crops Prod. 2004, 20, 59-65. [CrossRef]

13. Youssef, M.M.A.; Lashein, A.M.S. Effect of cabbage (brassica oleracea) leaf residue as a biofumigant, on root knot nematode, meloidogyne incognita infecting tomato. J. Plant Prot. Res. 2013, 53, 271-274. [CrossRef]

14. Mojtahedi, H.; Santo, G.S.; Hang, A.N.; Wilson, J.H. Suppression of Root-knot Nematode Populations with Selected Rapeseed Cultivars as Green Manure 1. J. Nematol. 1991, 23, 170-174. [PubMed]

15. Bangarwa, S.K.; Norsworthy, J.K. Brassicaceae Cover-Crop Effects on Weed Management in Plasticulture Tomato. J. Crop Improv. 2014, 28, 145-158. [CrossRef]

16. Salem, M.F.; Mahdy, M.E. Suppression of root-knot nematode through innovative mustard biofumigation. Future Food J. Food Agric. Soc. 2015, 3, 41-50.

17. Avato, P.; D'Addabbo, T.; Leonetti, P.; Argentieri, M.P. Nematicidal potential of Brassicaceae. Phytochem. Rev. 2013, 12, 791-802. [CrossRef]

18. Galletti, S.; Bagatta, M.; Branca, F.; Argento, S.; De Nicola, G.R.; Cianchetta, S.; Iori, R.; Ninfali, P. Isatis canescens is a rich source of glucobrassicin and other health-promoting compounds. J. Sci. Food Agric. 2015, 95, 158-164. [CrossRef] 
19. Al Shahawany, A.W.; Al Hattab, Z.N.; Al Tahhan, S.F. Qualitative and Quantitative Analysis of Sinigrin in Different Parts In Vitro and In Vivo of Brassica nigra Plants. Biomedicine 2016, 4, 19-24.

20. Hanschen, F.S.; Yim, B.; Winkelmann, T.; Smalla, K.; Schreiner, M. Degradation of biofumigant isothiocyanates and allyl glucosinolate in soil and their effects on the microbial community composition. PLoS ONE 2015, 10, e0132931. [CrossRef]

21. Dutta, T.K.; Khan, M.R.; Phani, V. Plant-parasitic nematode management via biofumigation using brassica and non-brassica plants: Current status and future prospects. Curr. Plant Biol. 2019, 17, 17-32. [CrossRef]

22. Gimsing, A.L.; Kirkegaard, J.A. Glucosinolates and biofumigation: Fate of glucosinolates and their hydrolysis products in soil. Phytochem. Rev. 2009, 8, 299-310. [CrossRef]

23. De Nicola, G.R.; D'Avino, L.; Curto, G.; Malaguti, L.; Ugolini, L.; Cinti, S.; Patalano, G.; Lazzeri, L. A new biobased liquid formulation with biofumigant and fertilising properties for drip irrigation distribution. Ind. Crops Prod. 2013, 42, 113-118. [CrossRef]

24. Sukovata, L.; Jaworski, T.; Kolk, A. Efficacy of Brassica juncea granulated seed meal against Melolontha grubs. Ind. Crops Prod. 2015, 70, 260-265. [CrossRef]

25. Aydinlı, G.; Mennan, S. Biofumigation Studies by Using Raphanus sativus and Eruca sativa as a Winter Cycle Crops to Control Root-knot Nematodes. Braz. Arch. Biol. Technol. 2018, 61. [CrossRef]

26. Branca, F.; Li, G.; Goyal, S.; Quiros, C.F. Survey of aliphatic glucosinolates in Sicilian wild and cultivated Brassicaceae. Phytochemistry 2002, 59, 717-724. [CrossRef]

27. Branca, F.; Argento, S.; Tribulato, A. Assessing genetic reserves in Sicily (Italy): The Brassica wild relatives case study. In Agrobiodiversity Conservation Securing the Diversity of Crop Wild Relatives and Landraces; CABI: Wallingford, UK, 2012; pp. 52-58.

28. Maxted, N.; Ehsan Dulloo, M.; Ford-Lloyd, B.V.; Frese, L.; Iriondo, J.M.; Pinheiro de Carvalho, M.A.A. (Eds.) Agrobiodiversity Conservation: Securing the Diversity of Crop Wild Relatives and Landraces; CABI: Wallingford, UK, 2012; ISBN 9781845938512.

29. Branca, F.; Chiarenza, G.L.; Ragusa, L.; Argento, S. Morphological characterization of the ECPGR wild Brassica species collection. Acta Hortic. 2013, 1005, 157-164. [CrossRef]

30. Mitsiogianni, M.; Koutsidis, G.; Mavroudis, N.; Trafalis, D.T.; Botaitis, S.; Franco, R.; Zoumpourlis, V.; Amery, T.; Galanis, A.; Pappa, A.; et al. The Role of Isothiocyanates as Cancer Chemo-Preventive, Chemo-Therapeutic and Anti-Melanoma Agents. Antioxidants 2019, 8, 106. [CrossRef]

31. Terzo, M.N.; Pezzino, F.; Amodeo, L.; Catalano, D.; Viola, M.; Tribulato, A.; Travali, S.; Branca, F. Evaluation of a sicilian black broccoli extract on in vitro cell models. Acta Hortic. 2018, 135-142. [CrossRef]

32. EEC. EEC Regulation No 1864/90, Enclosure VIII, Oilseeds-Determination of glucosinolates-High performance liquid chromatography. Off. J. Eur. Commun. 1990, L170, $27-34$.

33. Wathelet, J.; Iori, R.; Leoni, O.; Quinsac, A.; Palmieri, S. Guidelines for glucosinolate analysis in green tissues used for biofumigation. Agroindustria 2004, 3, 257-266.

34. Torne, G. Principles of Nematology; McGraw-Hill Book Company: London, UK, 1961; ISBN 9780198565260.

35. Allen, R.G.; Pereira, L.S.; Raes, D.; Smith, M. FAO Irrigation and Drainage Paper No. 56-Crop Evapotranspiration; FAO: Rome, Italy, 1998.

36. Lamberti, F. Primi risultati di prove di lotta nematocida su tabacchi levantini in provincia di Lecce. Table 1971, 738, 5-10.

37. Snedecor, G.W.; Cochran, W.G. Statistical Methods, 7th ed.; The Iowa State University Press: Ames, IA, USA, 1989; ISBN 0813815616.

38. Branca, F.; Tribulato, A. Brassica Macrocarpa; The IUCN Red List of Threatened Species: Cambridge, UK, 2011.

39. Galletti, S.; Fornasier, F.; Cianchetta, S.; Lazzeri, L. Soil incorporation of brassica materials and seed treatment with Trichoderma harzianum: Effects on melon growth and soil microbial activity. Ind. Crops Prod. 2015, 75, 73-78. [CrossRef]

40. Gimsing, A.L.; Kirkegaard, J.A. Glucosinolate and isothiocyanate concentration in soil following incorporation of Brassica biofumigants. Soil Biol. Biochem. 2006, 38, 2255-2264. [CrossRef]

41. Henderson, D.R.; Riga, E.; Ramirez, R.A.; Wilson, J.; Snyder, W.E. Mustard biofumigation disrupts biological control by Steinernema spp. nematodes in the soil. Biol. Control 2009, 48, 316-322. [CrossRef] 
42. Daneel, M.; Engelbrecht, E.; Fourie, H.; Ahuja, P. The host status of Brassicaceae to Meloidogyne and their effects as cover and biofumigant crops on root-knot nematode populations associated with potato and tomato under South African field conditions. Crop Prot. 2018, 110, 198-206. [CrossRef]

43. Ntalli, N.; Monokrousos, N.; Rumbos, C.; Kontea, D.; Zioga, D.; Argyropoulou, M.D.; Menkissoglu-Spiroudi, U.; Tsiropoulos, N.G. Greenhouse biofumigation with Melia azedarach controls Meloidogyne spp. and enhances soil biological activity. J. Pest Sci. 2018, 91, 29-40. [CrossRef]

(C) 2019 by the authors. Licensee MDPI, Basel, Switzerland. This article is an open access article distributed under the terms and conditions of the Creative Commons Attribution (CC BY) license (http://creativecommons.org/licenses/by/4.0/). 